\title{
When in Shipping, Do as Greeks Do: For a Successful Creation and Management of a Shipping Company Dealing with Tankers and/or Bulk Carriers
}

\author{
Alexandros M. Goulielmos1,2 \\ ${ }^{1}$ Marine Economics, University of Piraeus, Piraeus, Greece \\ ${ }^{2}$ Professor Emeritus of Transport and Shipping Logistics, Business College of Athens, Athens, Greece \\ Email: ag@unipi.gr,am.goulielmos@hotmail.com, agoulielmos@bca.edu.gr
}

How to cite this paper: Goulielmos, A. M. (2021). When in Shipping, Do as Greeks Do: For a Successful Creation and Management of a Shipping Company Dealing with Tankers and/or Bulk Carriers. Modern Economy, 12, 1537-1562.

https://doi.org/10.4236/me.2021.1210078

Received: August 7, 2021

Accepted: October 26, 2021

Published: October 29, 2021

Copyright $\odot 2021$ by author(s) and Scientific Research Publishing Inc. This work is licensed under the Creative Commons Attribution International License (CC BY 4.0).

http://creativecommons.org/licenses/by/4.0/

\begin{abstract}
We have written-down our maritime experience and especially we showed the fact that certain decisions have a substantial time element. These decisions had to be taken before, if we had the proper knowledge. We have showed what is this knowledge. One prime and important truth is that a shipping company is cost-dependent, and the successful shipping manager is the one who has obtained a clear and deep knowledge of costs. Amongst costs, capital cost is the Goliath, and this is determined at the time of purchase. In all maritime costs, a strategy can be applied as shown. What in fact we have suggested is that a clever shipowner starts and stays in the $2^{\text {nd }}$ hand markets! Given that certain shipowners are empirical, and only the new generation has obtained postgraduate education, and for our students, we provided an analysis of the shipping market mechanisms. A great lesson is that the price for shipowners is given, and only cost has to be adjusted. Unfortunately, since 2008, shipping markets remain depressed at 3199 units for the BDI in 23/07/2021 against 12,000 units' top. We showed something unbelievable for maritime history, which is that in 2004 a $2^{\text {nd }}$ hand ship priced $\$ 53 \mathrm{~m}$ more than the new-building one!! The crew cost has attracted our attention as the role of shipping is important to provide employment to nations and especially to poorer ones to the extent of $1.89 \mathrm{~m}$ persons. China could provide the 89,510 officers missing in next 5 years for the 74,000 ships, if it so wants, with rapid education in English. The important fuel cost was also presented. Is the next shipping fuel the hydrogen, or the ammonia, or the LNG? Can technical progress in shipping main engines bring a revolution? i.e., with
\end{abstract}


a new cheaper and environmentally friendly fuel? With a spot crude oil price of Brent in 2011 of US\$ 115 per barrel, the new fuel is a great hope! While the speed of the vessels is a strong technological factor; this is unfortunately connected to fuel consumption, as shown.

\section{Keywords}

Six Issues in Shipping Business to Be Taken in Time, The Shipping Market Equilibrium, The Role of Distances, Anatomy of Maritime Costs, $2^{\text {nd }}$ Hand Ship Prices in 2004, The International Labor Sea Cost, Crude Oil Prices, 1976-2011, Port and Insurance Costs

\section{Introduction}

The paper is addressed to a number of readers: 1) those who want to start-up their own shipping company (Picture 1);2) those who want to find-out how all those shipowners became rich; 3) those who are students of maritime economics-BSc ME and of Master of Maritime Business Administration-MMBA, who want to learn; and 4) last, but not least, to new and young managers who want to manage their shipping company with faultless actions just from the outset.

In shipping, there are faults that a manager may regret, if not careful from the beginning... It is valid here the proverb: "My last wisdom, I wish I had it before" ...

As shown in Picture 1, the things that one needed in order to become a shipowner in the past, were only... 10: (1) a vision (2) a vessel-liner ("Smith Lines"); (3) a shipping company ("ACME shipping $\operatorname{Ltd}^{1}$ ); (4) a room; (5) a desk; (6) a phone; (7) a few IMO instructions; (8) a file cabinet; (9) the only male-baby's photograph, and (10) a rather mature manager. The above was a simple picture,

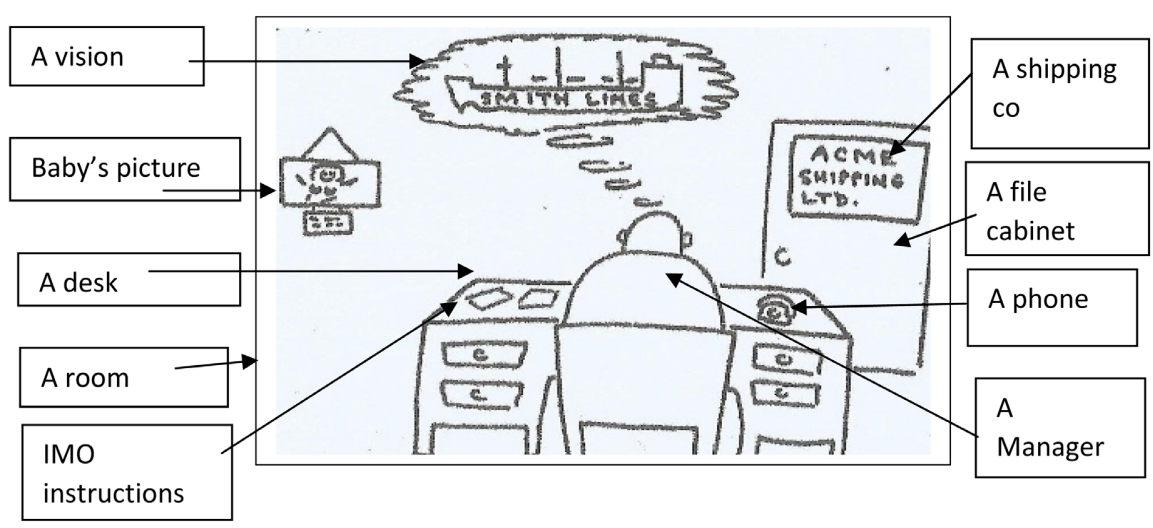

Picture 1. All those one used to need to become a shipowner in the past. Source: "Fairplay" publications; modified.

${ }^{1}$ The legal form of the ship-owning companies must be such so that claims against one vessel not to be extended to shipowners' other ships in the same fleet, but to be confined in shareholders contribution = the "share capital" of the vessel in question. Each vessel has her own company or companies. The "mother company" holds the shares of all ships in the fleet. The shares are anonymous. 
except for the vision, as today one needs also: a secretary; a mechanical engineer; an ex-Captain Manager; an old (near 20 years of age) dry cargo $2^{\text {nd }}$ hand ship of small size; and an assistant accountant.

Moreover, nowadays, one needs a number of personal computers, and the proper software, in the area especially of accounting etc. What is important and is not mentioned, in Picture 1, is the thorough knowledge of maritime costs. The shipowner who knows everything about costs, and he/she able to manage them, as the case may be, is the King.

\section{Aim and Structure of the Paper}

The purpose of this work is to warn tentative shipping managers about their decisions, which if not taken in time, they cannot be taken afterwards. We also show the relative importance of each cost item. This is the wisdom acquired by the author by working in a large Greek shipping company as a departmental manager, since 1977, and as a marine insurance company director.

The paper is organized in parts after its introduction and literature review. Part I deals with the issues that a shipowner has to face first. Part II deals with the issue to know in what market one is going to make business. Part III deals with the constitution of total maritime costs. Finally, we conclude.

\section{Literature Review}

Stopford (2009) devoted quite a number of pages to analyze shipping costs etc. (p. 217). He distinguishes them ${ }^{2}$ as due to a set of 9 factors (Graph 1).

As shown in Graph 1, fuel is the critical cost, determining also the quantity and cost of bunkers by taking into account the price of oil ( $\$ 300 /$ ton), and the consumption rate of the main engine ${ }^{3}$. The size of the crew determines basically the crew wages, among a number of other factors. The physical condition of the

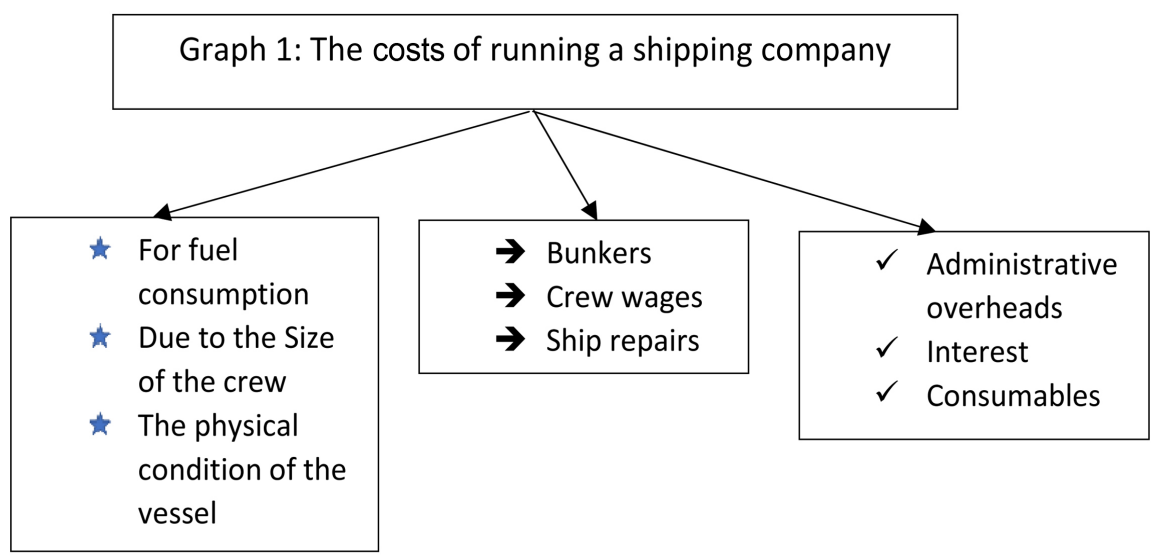

Graph 1. The costs of running a shipping company. Source: Data from Stopford (2009) (p. 221).

${ }^{2} \mathrm{We}$ use the term shipping when ports are not involved, and the term maritime when ports and canals are involved.

${ }^{3}$ Figure 12 . 
vessel determines the need for repairs, something which shipowners postpone during a depression. This condition, however, is something decided at purchase phase.

The cost to run a fleet from a shore office depends on a number of factors like the number of staff and their wages, nationality, IT infrastructure, etc., and on the efficiency ${ }^{4}$ of the shore manager. We have seen managers to maintain a very simple, but effective, office staff; this is what we mean by a skeleton (slimmed down; thin) organization to run a fleet. The administration cost (a fixed cost about $10 \%$ ) though small, it may arrive at $\$ 600$ - $\$ 800$ per day depending also on ship's flag and this, during a depression, may be important.

Subsequently, Stopford classified shipping costs in 5 categories (Graph 2).

As shown in Graph 2, the costs are distinguished in those that make a ship operational, i.e., ready to load, but before the voyage is undertaken. The costs that are covered when the vessel undertakes a voyage, which cannot be controlled by the ship's company, as even a specific speed is noted-down in the charter party, are called "voyage costs". Voyage costs cover also the cargo delivery costs. In a depression, shipowners by managing a lower $\%$ of their costs, i.e., $41 \%$ (= operating costs), they are not effective to face it, given that the majority of cost is out of their control (59\%). This is why that during a depression the wage bill is the first to be cut by say $20 \%$.

The costs for dry docking so that the vessel to retain her class, and the capital cost spent to buy/build the vessel, are fixed costs, and the lower, the better, as they cover more than $50 \%$ of total cost in a new building...! Worth noting is the

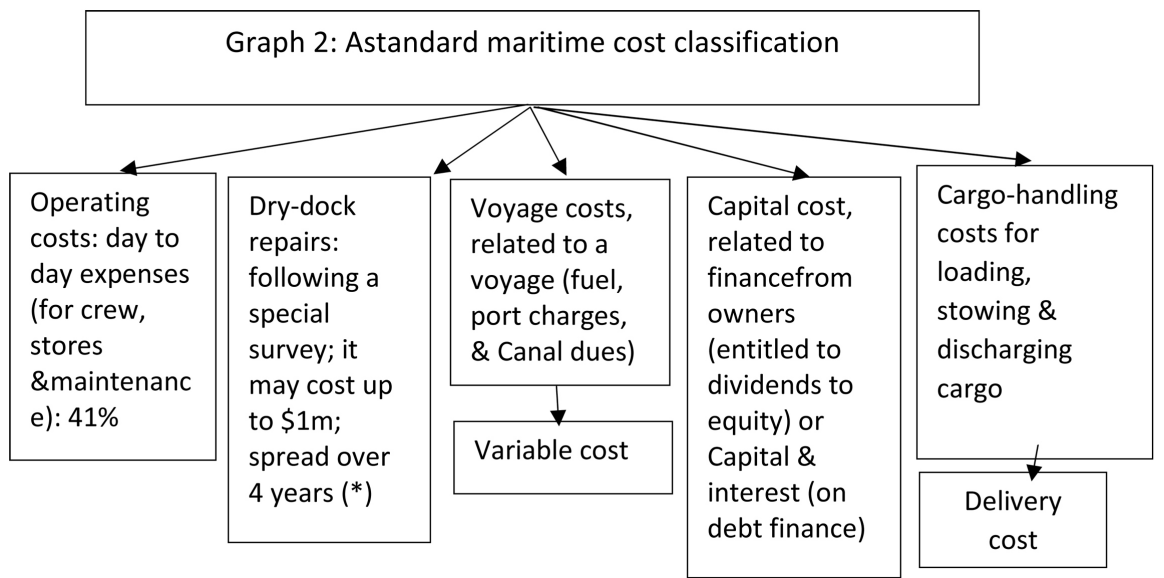

Graph 2. A standard maritime cost classification. Source: data from Stopford (2009: p. 221). $\left.{ }^{\star}\right)$ UK shipowners had as a policy to sell their ships when they approached the $3^{\text {rd }}$ special survey $(3 \times 4=12$ years), as the cost of this could be high (Goulielmos, 1974, PhD thesis); Greeks used to buy almost all these UK ships; then some repairs were carried-out by Greek crew and some at cheaper Greek repair yards....

${ }^{4}$ Companies which want to check all payments for their correctness, they have a larger office staff. A ship owning company running a fleet of 30 - 35 ships, may need 250 persons as staff, having an extensive "cost control". The company which does not care what cost is prevailing at shore and at sea and in ports, it may have a staff of 120 - 140 persons. The whole issue apparently is a matter of cost-benefit analysis. 
fact that the fuel cost may arrive at high levels and cover more than $20 \%$ of total cost. Here a shipowner may apply a strategy to avoid the increases in fuel cost during a voyage, by hiring his/her vessels in time charter. In time charters, voyage costs (and fuel) are paid by the charterer.

Subsequently, Stopford (p. 222-5) focused on 2 important relationships: 1) Cost and Age and 2) Cost and Size. Taking as an example a "Capesize" bulk carrier we see (Table 1).

As shown, all costs, but capital cost, increased as age increased. But we must stress that capital cost is the dominant item, which needs a special attention. Assuming a capital cost of $\$ 5 \mathrm{~m}$ p.a., a $15.5 \%$ discount in the $20^{\text {th }}$ year as shown in Table 2 ( $3^{\text {rd }}$ column), means about $\$ 775,000$ p.a. less... And this is higher than the $4 \%$ increase in the remaining costs (i.e., about $\$ 200,000$ p.a.)! Thus, the clever shipowner always seeks to achieve a low capital cost before anything else!!

As far as Size ${ }^{6}$ and Cost are concerned, Table 2 sets the picture.

As shown in Table 2, increasing the size of the ship by almost 6 times $\left(4^{\text {th }}\right.$ column), one increases income by more than 2 times, and the total operating cost p.a. increases by only $67 \%$ ! The capital cost increases by only 2.27 times.

Table 1. The relationship of Age and Cost in a "Cape-sized" bulk carrier, 2005.

\begin{tabular}{|c|c|c|}
\hline $\begin{array}{l}\text { Cost item in her first } 5 \\
\text { years, \& \% }\end{array}$ & $\begin{array}{l}\text { Increase in it in } \\
\text { next } 5 \text { years }\end{array}$ & $\begin{array}{l}\text { Increase in it in next } 10 \\
\text { years }\end{array}$ \\
\hline $\begin{array}{l}\text { Capital, } 47 \% \text {; } \\
\text { (8\% p.a. capital cost) }\end{array}$ & $\begin{array}{l}\text { Capital } 39.5 \% \text {, } \\
\text { (less } 7.5 \% \text { ) }\end{array}$ & Capital $24 \%\left(^{*}\right)$ less $15.5 \%$ \\
\hline Maintenance, $2 \%$ & Maintenance $3 \%(+1 \%)$ & Maintenance $5 \%(+2 \%)$ \\
\hline Voyage cost, $33 \%$ & Voyage cost $35.5 \%(+2.5 \%)$ & Voyage cost $40 \%(+4.5 \%)$ \\
\hline Operating cost, $18 \%$ & Ops cost $22 \%(+4 \%)$ & Ops cost $31 \%(+9 \%)$ \\
\hline Total $100 \%$ & Liberian flag & $\begin{array}{l}\left.{ }^{\star}\right) \text { Stopford assumed } \\
11 \% \ldots\end{array}$ \\
\hline
\end{tabular}

Source: Data from Stopford (2009), p. 222.

Table 2. Size and costs among 4 bulk carriers, 2005.

\begin{tabular}{cccc}
\hline 30,000 dwt $=100$ & $47,000=+57 \%$ & $68,000=+45 \%$ & $170,000=+2.5$ times \\
Price: $\$ 26 \mathrm{~m}$ & $\$ 31 \mathrm{~m}=+19 \%$ & $\$ 36 \mathrm{~m}=+16 \%$ & $\$ 59 \mathrm{~m}=+64 \%$ \\
Bunker consumption: & $24=+14 \%$ & $30=+25 \%$ & $50=+67 \%$ \\
$(21 \mathrm{t} / \mathrm{d} / \$ 300$ per ton $)$ & $1.4=+17 \%$ & $1.8=+29 \%$ & $2=+11 \%$ \\
Operating cost: $1.2 \mathrm{~m}$ p.a. & $13,657=+19 \%$ & $16,360=+20 \%$ & $24,374=49 \%$ \\
Income $=11,494=100$ & $\$ 143$ & $\$ 120$ & $\$ 74$ \\
Average cost $=\$ 191$ & & &
\end{tabular}

Source: data from Stopford (2009), p. 224; assumed 270 sea days at 14 k. Depreciation + interest $5 \%+6 \%$.

${ }^{5}$ In 2009 from 100,000 dwt to 180,000 dwt bulk carriers that they cannot pass Panama Canal.

${ }^{6}$ Stopford (2009), p. 224, argued that in 1870 the flexible ship size was 2,000 and in 2000 this was 25 times larger $(50,000)$. 
Shipping scale economies are apparent, provided there are big charterers (Goulielmos, 2021a). The last row is clear: the larger vessel of 170,000 dwt achieves average cost $\$ 74$ per ton of cargo ( $\mathrm{dwt}$ ) against $\$ 191$ (2.6 times less) of the smaller one of 30,000 dwt!

Lorange (2009) argued that shipping companies must keep their costs down. Sustainability in the long-term means lower cost than one's competitors! Certain countries face a high sea labor cost (Table 3), which may arrive at $41 \%$ of operating costs ( $\$ 663,000$ p.a.) under a Liberian flag.

Shipowners are aware of the sea labor cost worldwide and adjust accordingly their recruitment policy. They also know that well-trained seamen from Eastern Europe may have an inclination towards drinking; Philippines are inclined to specific food habits, but they know English, are obedient, are well-educated and have received nautical experience from Greeks, though of a lower level. Chinese are hard-working seamen by they have to improve their English. A good nautical education in China, especially by giving first priority to officers, and to the proficiency in English, will make Chinese to replace all other nationalities on board, and bring a lot of USA $\$$ home, together with a maritime know-how...

Summarizing, we presented an anatomy of the maritime costs and we recognized a strategy for shipowners to pursue "time charters", especially after 2004, when fuel prices increased in a continuous fashion. We also showed that a close control of fleet's cost needs a larger organization, and this whole matter is one of cost-benefit analysis. We insisted, however, that the shipowner who cares about his/her capital cost so that to be low, is the King! The relationships of age and cost and size and cost analyzed. Economies of scale were shown before any doubt. A rather extensive analysis was devoted to the sea labor cost, as this is the most important human element providing additional employment to a nation.

\section{Part I: The Issues that a Shipowner Has to Face First}

\subsection{Is Ship Management Know-How Necessary?}

To become a shipowner these days, one does not need to know shipping

Table 3. Sea labor per country, 2009.

\begin{tabular}{llc}
\multicolumn{1}{c}{ Country } & \multicolumn{1}{c}{ Sea labor cost } & \multicolumn{1}{c}{ Remarks } \\
\hline Norway & Higher seafarer wages & Vis-à-vis Sweden \& Denmark \\
$\begin{array}{l}\text { Former Yugoslavia, Russia, } \\
\text { Eastern European countries, } \\
\text { India, Philippines }\end{array}$ & Low sea labor cost & \\
$\begin{array}{l}\text { Greece }\left(^{*}\right) \text { and others shipping } \\
\text { traditional countries }\end{array}$ & & Tax relief to seamen \\
Netherlands, Sweden, Denmark & & Total tax freedom to crew \\
\hline
\end{tabular}

Source: Lorange (2009), p. 256. $\left(^{*}\right)$ Taxes are paid to help home-state to cover its expenses for the citizens living-in, but seamen live on board... that is... abroad, if ship flows a foreign flag. So, as we have argued elsewhere seamen must pay taxes according to their time of stay in their country! Of course, the space of the ship is equivalent to the land of flag's country. 
business ${ }^{7}$, (i.e., this is not a necessary condition), if one's staff does! If one knows shipping business, this is surely an advantage, (i.e., a sufficient condition). One $3^{\text {rd }}$ party management company charged for a Cape, 5 years old, a fee of $\$ 7$ per day. The choice of a $3^{\text {rd }}$ party management company gives an opportunity for a clever strategy (Goulielmos, 2021a). For a new unknown owner-not known even by one's porter in the block of flats one lives-the appointment of well-known international management company looking after 600 - 700 ships is acceptable by international charterers...

\subsection{Is Capital Needed, as Well a Working One?}

To obtain a vessel, which will make one... a "ship-owner", one has to possess an at least $20 \%$ of her price, usually in USA $\$$ (or $€$ ). This amount may be derived from past savings, or from a number of friends, who will pull their savings together, etc. The availability of initial capital is a necessary condition, but not a sufficient one for one to become a shipowner. The remaining $80 \%$ of the capital will be added by a bank under certain prerequisites (Goulielmos et al., 2010). For Greeks now, and after they joined EU, and especially European monetary union, established in 1979, they have an international currency now in hand $(€)^{8}$ to buy ships.

One needs also a working capital. The working capital is essential, despite that many owners ignore or bypass this, especially in the past. "Working capital" can simply be defined as: "the $\$$ amount needed by a shipowner to buy various basic items, before, and till, ship's initial income from freight/hire, arrives-in at company's bank". The vessel, e.g., has to obtain bunkers, water, and stores. This is why certain shipowners are happy when the "freight is prepaid"!

For a vessel assuming to have a year cost of $\$ 8.6 \mathrm{~m}$ ( $2.1 \mathrm{~m}$ operating cost; $0.5 \mathrm{~m}$ maintenance; $6 \mathrm{~m}$ voyage cost) travelling for 20 days till she gets the first freight, she needs $\$ 23,562 /$ day or $\$ 471,233$ per voyage working capital. The fuel cost is calculated at \$300/ton (Stopford, 2009: p. 224-225).

Moreover, a shipowner has to establish an office at shore, because the days when a shipowner was on board of his single vessel, in owner's cabin, are passed away forever, since round or before 1960.

\subsection{Has the Vessel to Be Seaworthy and Insured?}

The vessel has to certify herself that she is seaworthy, and to obtain an insurance

${ }^{7}$ It is of great importance to point out that the " $3^{\text {rd }}$ party ship managers" are available massively since 1980-1990. These undertake the management of the ships of another owner for a fee for all or part of his/her needs (Goulielmos et al., 2011). As shown above, the fee was about $\$ 7$ per day and it seems that age does not increase it! These companies have also established international seamen schools and they can cover any crew needs an owner has.

${ }^{8}$ Given that shipping earns USA $\$$, the parity $\$ / €$ plays a role. This is also valid if one pays crew wages in $€$. In the past Greek crews were paid in $£$ and then in $\$$ due to the troubles of the pound. After 1979 or so they are paid in $€$. The Greek shipping policy committed a mistake by paying foreign sea labor as equal to Greek till 1983 out of the fear of discrimination! Wages must reflect productivity.

${ }^{9} \mathrm{This}$ is the freight payable before carriage is performed. 
cover for all sea perils, also, she has to become a member of a P \& I Club ${ }^{10}$. Certain maritime countries like Greece attempted, but failed, to establish a national $\mathrm{P}+\mathrm{I}$ club. Latter we will talk about the strategy of what is called a "deductible" amount.

The "hull and machinery" insurance cover, as its name indicates, does not cover all sea dangers, especially those threatening: crew, cargo and sea (with pollution) etc. In shipping, all sea risks are covered, even the loss of income from strikes, etc.! When one tells me that shipping businesses are very risky, I tell him/her that this is perhaps the only industry, where all conceivable risks can be insured, even for the case of an earthquake while the ships are in a port! The owner needs about $\$ 196,000$ p.a. or $12 \%$ of total operating cost for a 5 years old Cape to insure her, of which $\$ 63,000$ for a $\mathrm{P}+\mathrm{I}$ Club, managed by a $3^{\text {rd }}$ party ship management company.

The seaworthy property, and the relevant certificate issued by a "Classification society ${ }^{11 "}$, are required before the ship can be insured! We do not recommend according to our experience to anybody to manage (own) an uninsured vessel! The proper insurance value can be determined by the formula $\{1\}$ below without paying money to official valuers.

The insured value, needing a strategy, must be at the level of ship's market value as frequent as possible, especially when market is on a rising-up trend. The ship in a marine accident, which we do not wish, will be paid her insured value! If a shipowner economizes on insurance premiums, and suppose he/she insures the ship at $50 \%$ of her value, say $\$ 10 \mathrm{~m}$, in a "total loss", he/she will be paid this amount (and this will mean a loss of $\$ 10 \mathrm{~m}$ ). We know that insurance companies adjust insured ship prices once in a year at the so-called "renewal" time.

\subsection{Has One to Buy a $2^{\text {nd }}$ Hand Vessel...?}

Worth noting is to stress that those starting-up their own shipping company, have to pre-study carefully, and write-down, all the pre-conditions they wish to seek in buying-out a $2^{\text {nd }}$ hand vessel! "Precaution is indefinitely better than cure" here! Many shipowners underestimate this stage of buying a used ship. Many

\footnotetext{
${ }^{10}$ Associations of shipowners, who through contributions (calls; and supplementary ones at the end of the year), provide mutual protection against liabilities not covered by insurance (injuries to crew and loss or damage to cargo). The selection of a club is a strategic decision as the amounts to be paid may be large. One selection criterion should be if the ships already in the club are either in the category of having, in the past, the fewer crew illnesses or cargo claims etc., or are all of low vintages. All clubs keep detailed data on the claims they have paid and the reasons of payment. As the clubs believe in the musketeers' principle: "all for one and one for all", this means that those ships (the majority) who do not create claims have to pay for the claims created by the others, which are bad, and may be also a minority. This is surely wrong and unfair. Other criteria may be the nationality of the shipowner, the nationality of crew, the flag of the vessel and its particular trade and area... and all these causes that make a ship prone to a loss of cargo or damage to it etc. From our experience the cargo claims are the most frequent.

${ }^{11}$ Private or state organizations that care for ships to be built according to technical rules securing safety etc. These ships are registered etc. then in the classification society, or class, which supervised her construction. A number of classes formed the international association IACS (10 = 1/5); Japan; UK; USA; Norway; Germany; France; S Korea; China; Russia and Italy.
} 
shipowners appoint a mechanical engineer to make the so-called "superficial inspection" of the vessel to be bought! The care has to be double with a $2^{\text {nd }}$ hand ship via-à-vis a newly built, because as her $1^{\text {st }}$ owner designed her for a specific trade in mind, perhaps different than the one the $2^{\text {nd }}$ buyer has in mind.

Of course, the real reason of selling her has to be found-out. Our experience has taught us that ships may be sold after having/obtaining a defect ${ }^{12}$ or after a prior damage, fire, etc. Mistakes committed at this stage, i.e., at the time of purchase, they will follow the vessel till her sale or scrapping...

Onassis inspected the 3-2 ${ }^{\text {nd }}$ hand-vessels he bought from the Canadians, personally, with the assistance of an engineer... Onassis inspected the vessels, not to see their technical suitability for the trade he had in mind, but to find-out arguments/points to reduce the money he was going to pay... which he did down to 1/3 (Goulielmos, 2021b).

Thanks God, shipping industry has a well-organized $2^{\text {nd }}$-hand market, and Greeks in the past bought from there some 1000 ships in one year. This is so because in the $2^{\text {nd }}$ hand market one enters into the industry the cheapest possible way, and at the same time he/she is also competitive. This market is indeed for the shipowners who are poor as Greeks used to be!

It is true that the $1^{\text {st }}$ owner bears the full cost and risk of the vessel he/she builds and of her possible high price. The $2^{\text {nd }}$-owner gets all the benefits there exist, as the vessel when she enters into the sea for the first time, like private cars, gets automatically a price lower by about $\$ 734,000$ p.a., as shown below for a Panamax. Age deducts value from the ships under normal circumstances! One more year on the shoulders of a vessel, means almost $\$ 1 \mathrm{~m}$ less in her value, under normal conditions.

Using Equation (1) below, we see that the value of a ship falls ${ }^{13}$ from $\sim \$ 19 \mathrm{~m}$ at her 0 year (delivery) to $\sim \$ 15 \mathrm{~m}$ at 5 years of age! This is the age preferred by Greek shipowners to buy ships!

$$
Y=\text { ship's value }=-0.7337 x+18.803
$$

where $x=$ age in years, 36 observations.

The above regression was based on data covering 9 months in 2002 (Figure 1 ). Notable is that as $n \rightarrow \infty$, any regression becomes more reliable. This experiment indicates that managers must organize first all the information they are going to use, to manage the company, in co-operation with IT department (former EDP). To run a regression for each type of ship the company owns, as the above, is easy and data are now available from "specialized data houses" for almost everything one wishes to learn.

\footnotetext{
${ }^{12}$ When I was working with an International Bank and run the shipping finance department, a shipowner-client came-in and told me that he is going to visit/inspect the vessel $\mathrm{X}$ with an intention to buy her. Another shipowner-client of me, had already inspected the same ship and told me that he has found her suffering from sag (to)! This means that the center of the ship is depressed below the level of her 2 ends. I told them. They cancelled their visit, but because they saved a lot of money, they wanted to thank me extensively...

${ }^{13} \$ 734,000$ per year rounded.
} 


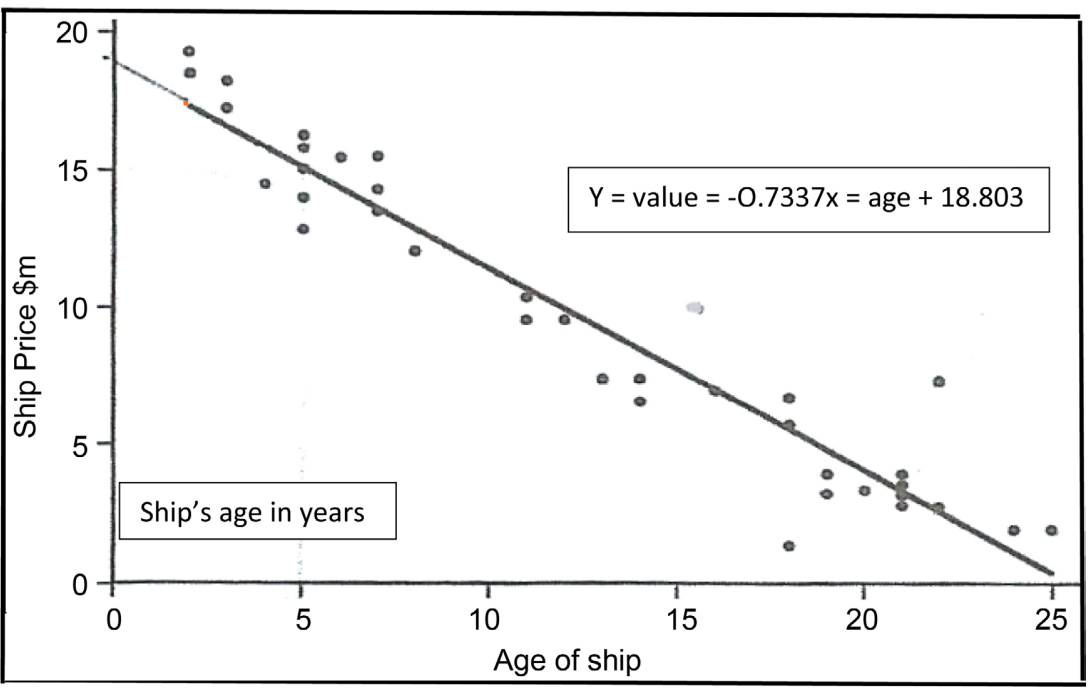

Figure 1. The Regression line between the value of a ship (Panamax bulk carrier, sold in 2002) and her age. Source: Stopford (2009), p. 239; modified.

Equation (1) is the result of fitting a regression equation to a set of 36 data points, by the method of ordinary least squares-OLS, establishing a quantitative economic relationship by estimating the values of the parameters $a$ and $b$. The above is a linear regression between age and price of a specific ship. Age is the independent variable. By inserting e.g., a particular age in the Equation (1), say for a vessel of 10 years old, we get an estimation of her price of $\$ 11.47 \mathrm{~m}$.

\subsection{Does One Gain Any Competitive Advantage as a $2^{\text {nd }}$ Hand Owner?}

One may ask what exactly is the benefit to buy a ship from the $2^{\text {nd }}$ hand market vis-à-vis the same from the new building market? One great benefit is that one pays less!

As shown in Figure 2, $\$ 19 \mathrm{~m}$ is the larger difference in 1982, and the higher benefit of a $2^{\text {nd }}$ hand buyer. In 1991, the $1^{\text {st }}$ owner pays $\$ 38 \mathrm{~m}$ (top), while the $2^{\text {nd }}$ owner pays $\$ 4 \mathrm{~m}$ for a used ship of 60,000 dwt and 5 years old in 1985! In 1991 the $2^{\text {nd }}$ hand ship-price is $\$ 18 \mathrm{~m}$. The $2^{\text {nd }}$ owner builds a strong competitive advantage in all these 18 years by buying from the $2^{\text {nd }}$ hand market! It is obvious that there is a timing strategy here (Goulielmos, 2021c).

However, to be accurate there is an exception in above history, in 2003 and 2004, as shown below ${ }^{14}$, where $2^{\text {nd }}$ hand ship prices increased above the newbuilding ones!! This is so because a great demand for ships could not be satisfied by new buildings due to their waiting and construction time, and the $2^{\text {nd }}$ hand ones were rare as everybody wanted to get rid of the exceptional high freight rates at that time...

\subsection{Should One Have Partners?}

Our experience has taught us that the choice of partners is of utmost importance ${ }^{14}$ Figure 7. 


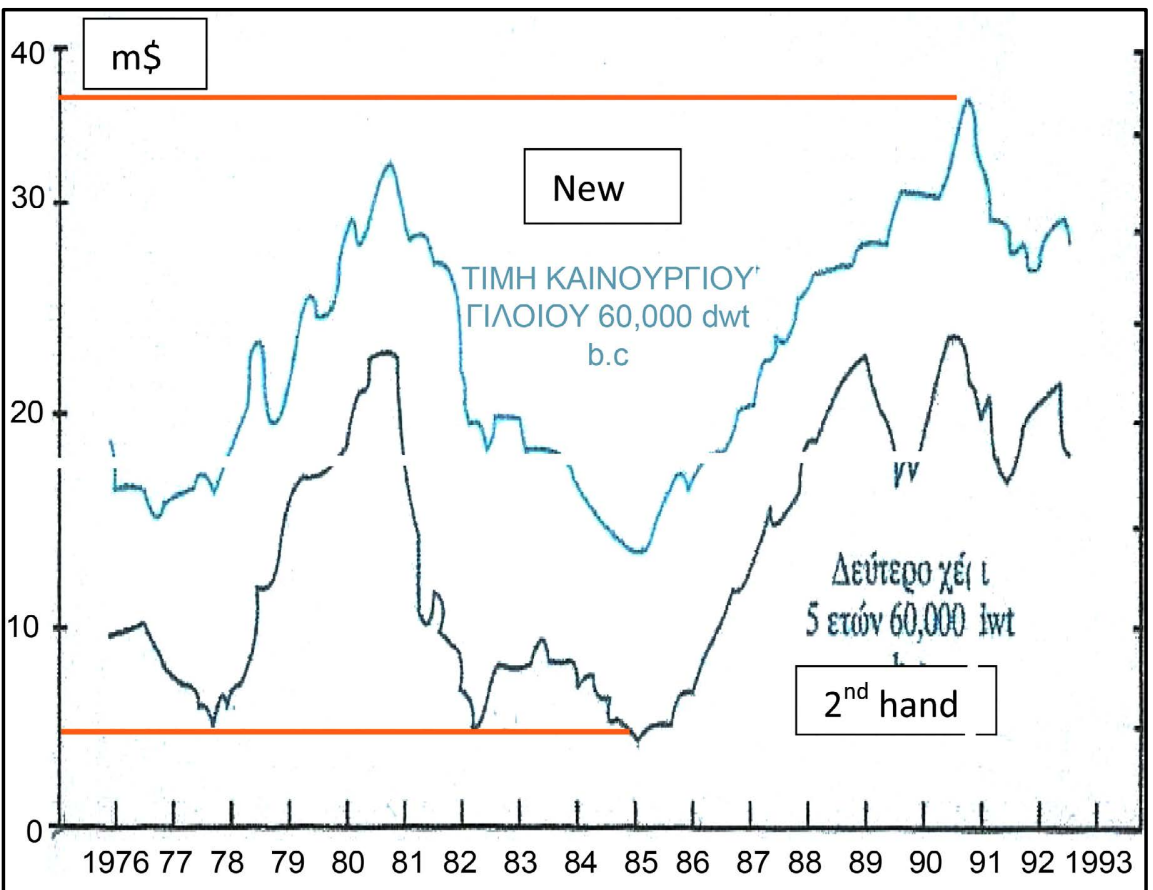

Figure 2. The level of the prices of newly-built ship and the $2^{\text {nd }}$ hand one, 1976-1993 (18 years). Source: author.

when forming a company. Many shipowners invite their close relatives, but some have regretted it. Captains invited partners ex Chief Engineers, but some have regretted it. Some shareholders appointed a Captain as Manager, but regretted it too, as he wanted to get all commissions from everything bought by the company for himself.

Some shipowners appointed a technical manager, but he got money/gifts from ship-repair yards and shipbuilders $(\$ 60,000)$. My experience has taught me that "the pocket of one person is much closer than company's pocket"!

Once, relatives/partners, sued a shipowner-manager ${ }^{15}$. A partner-brother-inlaw-arranged all hires to be deposited into his personal account... and the company run out of cash! Three partners, one marine engineer at the office and two brothers... in the night clubs realized that company's cash finished. All three had the right to sign cheques... without the signature of the other two at the same time...

A company's disbursements chief bought suddenly a Lamborghini private car... A branch manager abroad-in a sister chartering company-arranged for part of the commissions to be deposited in his account, then he became a shipowner. Many shipowners told me cases for lending money, or buying shares, which were all fake, and lost their money. One Captain telegraphed to the office of the vessel: "I confirm the receipt of 2 tons of paints, 1 ton I ordered, and 1 ton... sent by you"!

\footnotetext{
${ }^{15}$ People who put their money in a shipping company at its start consider their contribution great; people who manage the company consider their contribution greater. Frequently such disputes are solved in courts!
} 


\subsection{One Important Shipping Rule!}

Shipping: Trust no one! Great money is lost from various fake charterers as well. Here the principle is: "if you checked a charterer once for reliability, check him again and again"! The third time is the one you going to find out who is who, but it may be too late. All the above cases were real.

\section{Part II: Know in What Market One Is Going to Make Business}

\subsection{Equilibrium in Shipping Markets}

The knowledge of the market in which one shipowner is going to do business is the first lesson that one has to learn well! In the market of tankers and bulk carriers, one finds 3 variables: 1 ) the freight rate (or hire), meaning the price that is paid to ships for their transport services hired by charterers. 2) The active supply of shipping services, in million tons, meaning the ships owned by all global shipowners offering currently services. These services are distinguished mainly by trade (oil; dry cargo) and by ship's size by various name (e.g., Pana$\max ^{16}$; Cape; Suezmax; etc.) indicating the ability of the ship to cross various canals, and by their dwt (e.g., 80,000; 140,000; 100,000 etc.).

3) The demand meaning the quantity of seaborne trade, in billion tons, is the third and most important variable. The demand is the king in shipping, but this is influenced by... distances (shown below), except by its volume!

The equilibrium of a shipping firm and its industry are next shown (Figure 3).

As shown, the (higher) freight rate is determined by Supply 1 and Demand 1 (OF1) for the industry. At $\mathrm{OF} 1$ the vessel maximizes her profit $(\mathrm{AC}=\mathrm{MC}=$

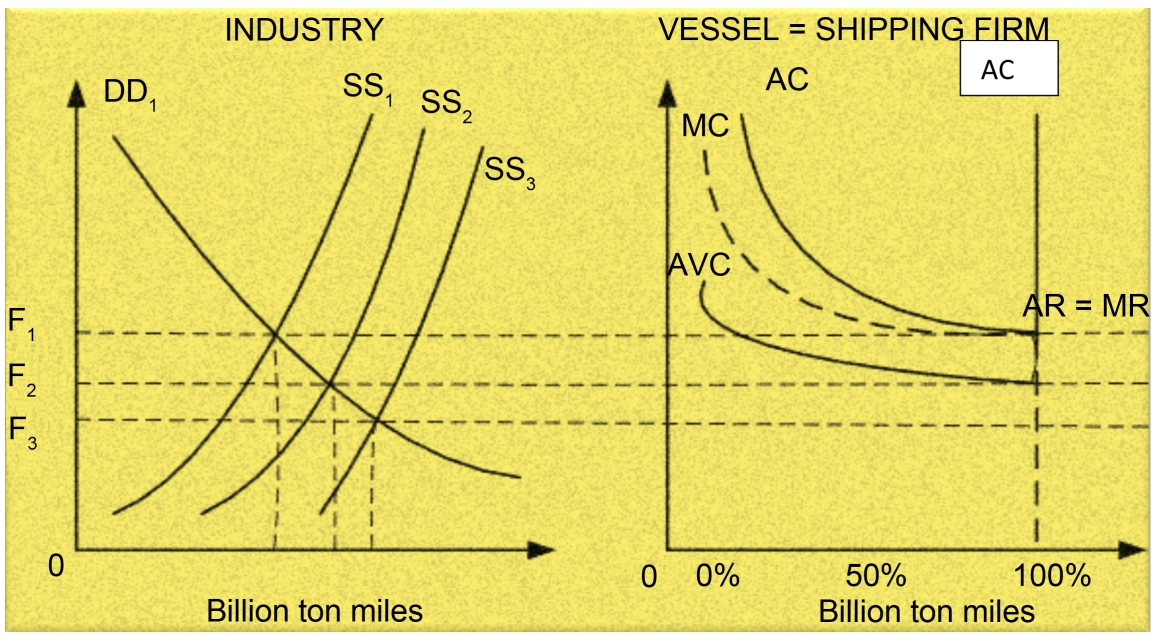

Figure 3. Equilibrium of a shipping firm and her industry. Source: author.

${ }^{16}$ Of proper dimensions to be able to pass panama Canal loaded. The Suez canal fees for a tanker crude carrier is done by a scale. The first 5000 SC net tonnage pays 7.88 SDR (special drawing rights) or $\$ 11.24$ for loaded transit $(7.88 \times 1.4264 \$)$. Next 5000 pay 5.58; the next $10,0004.22$ and the next 20,000 2.09. The dry bulk carriers pay more, i.e., $8.27 / 6.32 / 5 / 1.83$ than tankers. 
$\mathrm{AR}=\mathrm{MR}=\mathrm{OF} 1)$, provided her dwt is fully used (95\%). Average and Marginal cost of the vessel are falling, till she loads cargo at her $\mathrm{dwt}^{17}$ minus $5 \%$, where afterwards they rise vertically (zero elasticity of supply).

If now a new-building enters the market $(\rightarrow \mathrm{SS} 2)$, the freight rate falls to OF2, and vessel covers only average variable cost. If further deliveries of new buildings take place, and scrapping and laying-up of existing ships are inadequate to counteract Supply's rise, the freight rate will further fall to $\mathrm{OF}_{3}$. At $\mathrm{OF}_{3}$ the vessel has to be laid-up.

At $\mathrm{OF}_{3}$, the lay-up cost per ton per day is less than the (voyage and operating) cost per ton per day, since a loss occurs by chartering the vessel at $\mathrm{OF}_{3}$. This loss is greater than the "loss" (= expenses) of laying her-up ("minimization of loss"). The time of deciding about laying a ship up varies; in practice, this decision takes about maximum 3 years among Greeks from the time when freight rate is at $\mathrm{OF}_{3}$ and remains there for some time.

The basic lesson we learn from the above analysis is that the individual vessel and the single company has to accept whatever freight rate is determined by Supply and Demand. If this is low, the cost of the vessel has to be adjusted down accordingly. The industry is cost-driven, not price driven (Figure 4). This is important to remember always!

As shown, the 2008 highest in the Baltic Dry Index was near 12,000 units and in 2021 this fell-down almost 4 times to almost 3200 !

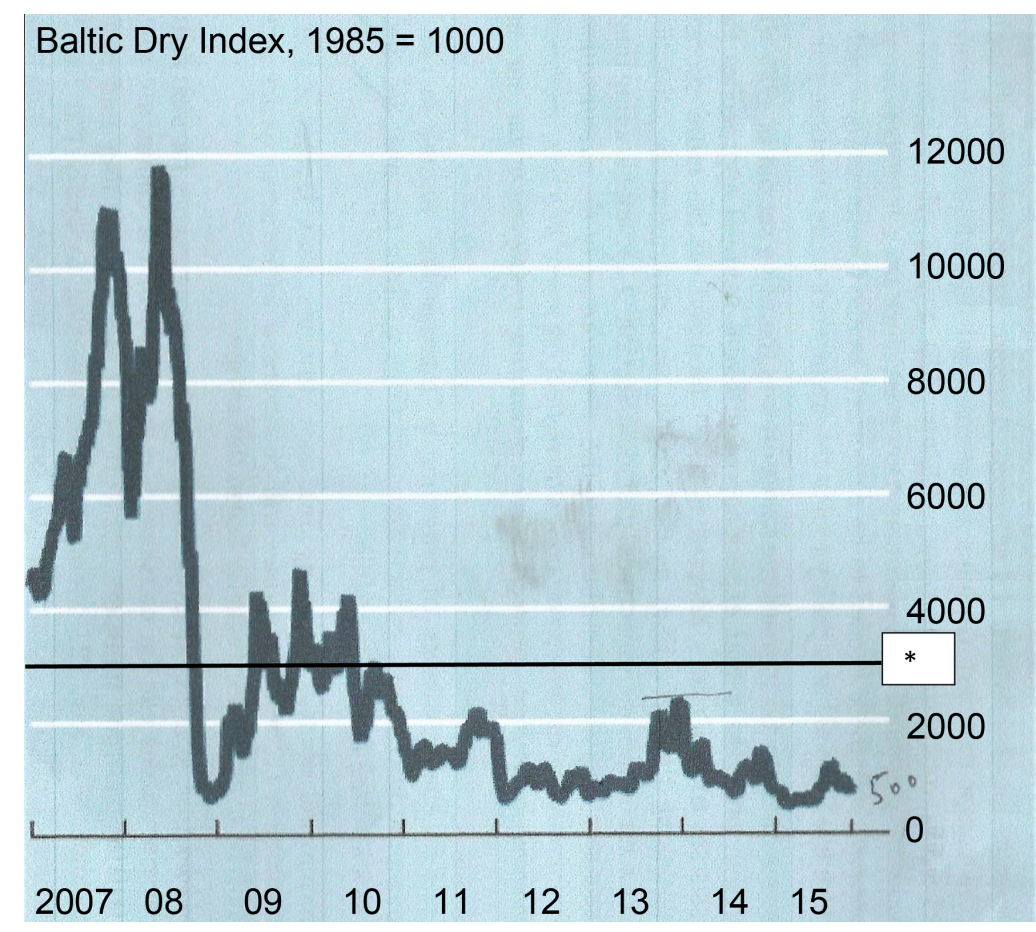

Figure 4. The baltic dry index $(1985=1000), 2007-2015$. Source: Thomson reuters. $\left.{ }^{\star}\right) 3199$ units in 23/07/2021. 1985 a depression year.

\footnotetext{
${ }^{17}$ The weight of bunkers, water, paints, etc. and of extra equipment-fixed constructions added after
} measuring ship's dwt, all reduce cargo that can be transported to reach load lines. 


\subsection{The Role of Distances}

Talking about distances, the Suez Canal, which opened in 1869, provides a distance-saving of 5100 n.m. for a journey from Indian Ocean (Mumbai) to London (Picture 2)!

If the ship has a 20 knots speed, she saves 10.63 days using Suez Canal. The average, per ship, revenue for the Canal was in 2010, minimum $\$ 270,000$ (\$5b/18,500 ships). In 1992, the Canal charged $\$ 295,000$ for the transit of a ship of 250,000 dwt ballast and $\$ 135,000$ for a loaded ship sized 60,000 dwt.

We believe that Canals by assuming that a medium sized vessel runs at say $\$ 7000$ per day and by saving 10 days using the Canal, she saves $\$ 70,000$, then canal may charge an amount in proportion of ship's benefit, but not more. We

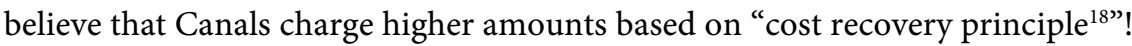

The history of shipping distances is shown below (Figure 5). Almost 2,000 miles were gained since 1989. This means that demand fell by almost $25 \%$ !

As shown, the top distance occurred in 1976 of 6695 sea miles. During the depression 1981-1987 distances diminished. In 1991, 5268 sea miles were top and stabilized-down at 5000 in 2005.

\section{Part III: The Constitution of Total Maritime Cost}

This part is very important as costs indicate the ability of a shipowner to be a competitive manager. In Figure 5, we presented the total cost in \%, for a new-building tanker, with a costly flag (USA), of a 30,000-dwt size.

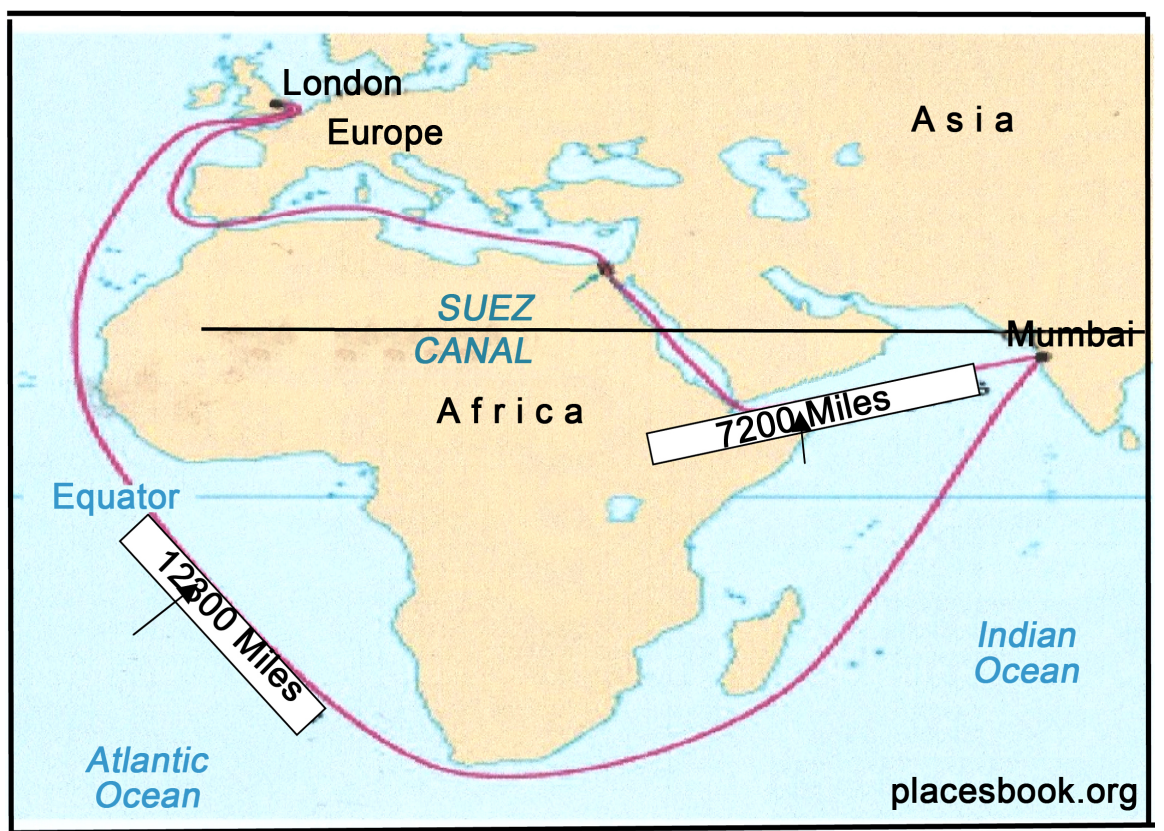

Picture 2. The Suez Canal shorter route by 5100 n. Source: placebook.org. modified.

\footnotetext{
${ }^{18}$ Meaning that Canals and Ports when they carry-out substantial investments for the sake of their users, they find it proper to recover the cost of the investments from users in a certain amount of years by increasing tolls and tariffs.
} 


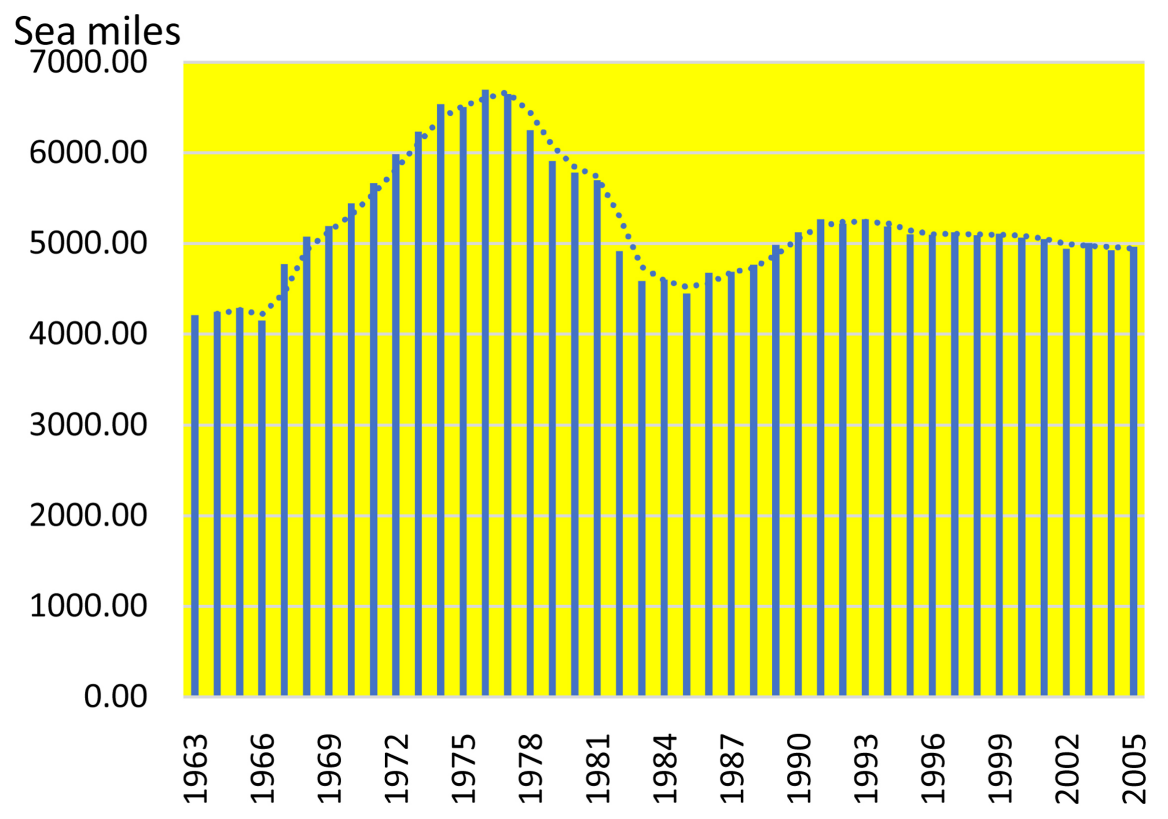

Figure 5. Distances covered by tankers on average, 1963-2005.

Our suggestion is that when one wants to save on costs, he/she has to start from the big ones. The capital cost is always the single big item, and in this case-study, includes the construction cost (price $=\$ 42.4 \mathrm{~m}$ here) amortized over 20 years at $16 \%$ p.a. interest ${ }^{19}$ rate providing an amount of $\$ 4,980,000$ p.a. to be recouped.

As shown in Figure 6, the big item here is capital cost, $51 \%$ in total cost, as mentioned. This is mainly determined by the price at which the ship was (bought or) built and the phase of the shipping cycle. The $2^{\text {nd }}$ hand ships may have a $30 \%$ share in capital cost (a 20\% saving). This tells us how important is timing in shipping business (Goulielmos, 2021c).

Figure 7 below confirms this. The full understanding of ship costs and of the factors that shape them, is very important this why we talk about "managing ship's costs" not simply paying them (Spencer, 1987).

\subsection{The Capital Cost $\sim 51 \%$}

As shown in Figure 7, the red columns indicate the $2^{\text {nd }}$ hand ship prices of one and the same vessel, and the blue columns the prices when ship was newly-built. The prices are unequal and in 1991 (number 1) the newly-built price was $\$ 14 \mathrm{~m}$ higher. But in 2003 (number 13; \$13 m) and especially in 2004 (number 14), the $2^{\text {nd }}$ hand ship prices became higher, as the vessels to buy were rare, due to the extremely good freight rate market due to China's boom!!!

In 2004, the $2^{\text {nd }}$ hand vessel cost $\$ 53 \mathrm{~m}$ more than the newly built one!! The order restored in 2005-2009. Excluding the exceptional period of 2003 and 2004, the cheaper entry into the market is through the $2^{\text {nd }}$ hand market, where a

${ }^{19}$ The interest that provides $\$ 4,980,000$ p.a. is rather near $12 \%$ and not $16 \%(=11.7454 \%)$. 


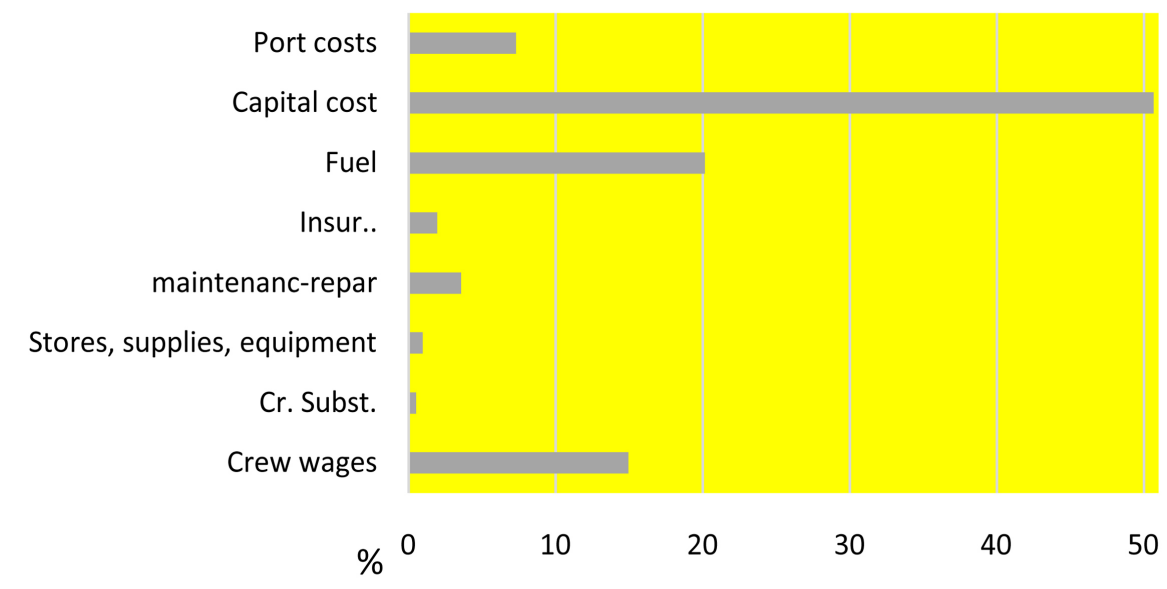

Figure 6. Total tanker cost of a new ship between Texas \& N Jersey, 1980s? Source: Author; data from Buckley (2008), p. 369.

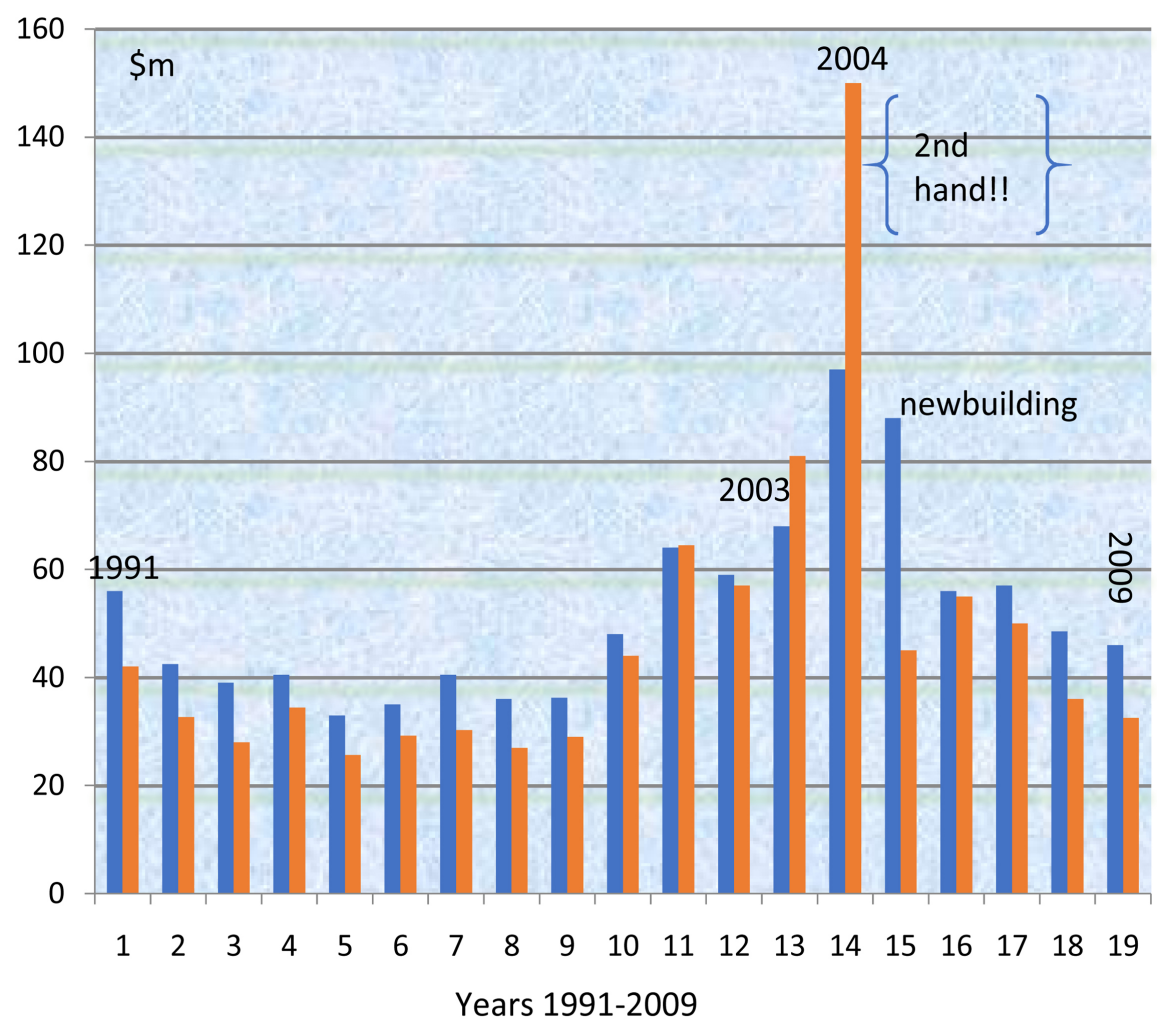

Figure 7. The Prices of a Newbuilding and the prices of her $2^{\text {nd }}$ hand price, 1991-2009. Source: author.

"discount" of $\$ 43 \mathrm{~m}$ can be obtained (2005; number 15)! It is recommended that when one is about to buy a new, and especially a $2^{\text {nd }}$ hand ship, to choose, or ask for, always, a rock-bottom price! This is a basic investment policy.

By paying attention to capital cost, one may disregard interest cost, which is based on LIBOR (the London interbank offered rate). The 12-months LIBOR was as follows (Figure 8).

The 12-months interest rate basis-LIBOR varied from a high $9.7 \%$ in 1989 to 


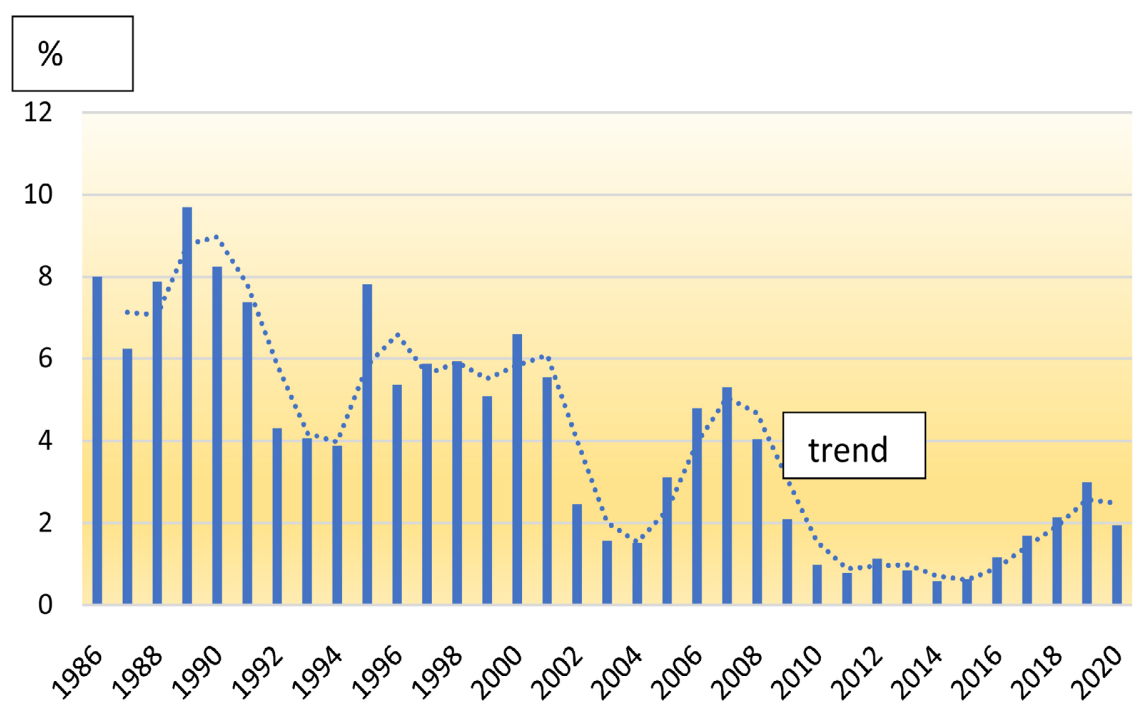

Figure 8. A 12-months LIBOR, 1986-2020. Source: data bought from Macro-Trends, January of each year.

$0.58 \%$ in 2014 ! The perfect timing to borrow is apparently from 2009 to 2020 (except 2019), at a rate-basis below $2 \%$ ! Global financial crisis apparently had a beneficial impact! Also, the Pandemic brought a few positive developments, apart from the cheaper oil and the reduced pollution. Greece e.g., borrowed $\$ 2.5 \mathrm{~b}$ in end-Jan. 2021 at a... negative interest rate! While fuel oil became expensive, the rate of interest became very low!

Borrowing, of course, is not an end per se, but the borrowed money has to be used for a project to provide a net return above the cost of borrowing $\{2 \%(+$ $\mathrm{x} \%)\}$ for 6 - 8 years! In a global pandemic, and a Delta variation, as now, the present value of the future long-term profit $\%$ is expected to be $<$ the cost of money \%, plus a risk \%, which is now high, times a low level \% of "the degree of confidence".

The maritime indicator (BDI e.g., as shown ${ }^{20}$ ) allows to have no hopes for a recovery. But timing is above pessimism as Great Greek shipowner Mr Procopiou G. stated in 2016: "Buy now and buy cheap"! Buy ships under a Pandemic crisis...? Is this a serious advice from a top Greek shipowner? Yes, if ships are cheap at rock bottom prices. Important is not the "buy now", but the buy cheap (Goulielmos, 2021c)!

It goes without arguing that small loan-amounts, quickly repayable, or no borrowing at all, are preferable than a heavy borrowing. Though banks and stock exchanges undertake the greater \% of risk of a shipping project, because they finance more than $50 \%$ of the market value of the project (by undertaking in fact the $80 \%$ on new-buildings) they become partners (!), and in default times, they may become owners ${ }^{21}$ as well...

Clever shipping companies (Navios e.g.) constantly pay attention to financial ${ }^{20}$ Figure 4.

${ }^{21}$ Through first preferred mortgage. 
costs and always try to find-out the cheapest finance sources, i.e., the "rock bottom interest rates". Moreover, whenever possible, shipping companies replace loans with high interest rates by ones with lower. Also, they raise money from stock exchanges to replace/repay-out expensive bank loans. In addition, they try to extend tenor with bank loans during bad times (depressions) through a re-negotiation.

Elsewhere, we have suggested even unequal loan installments based on the real cash flow of a shipping company, along with the prevailing shipping cycle, to avoid defaults: say a \% of gross earnings. Apropos, Goulielmos (2021d) argued that banks and Stock exchanges unfortunately do not understand the fact that shipping cycles... and volatility, are extremely useful phenomena! But to prefer a rock-bottom price is advisable than to prefer a low interest rate.

\subsection{The Crew Cost $15 \%$}

The presence of labor in the worldwide shipping industry has diminished substantially over the recent decades: in 1920 the number of men on ships were: 245,000 and in 1978 were 77,477 (or -316\%) (Alderton, 1980)! The sailing ships were indeed labor-intensive, of some 55 persons, but the steel made ships became capital intensive. The hope to be more competitive is rested on stronger, but lighter steel. Also, on smaller but cheaper and of slow speed engines consuming ... hydrogen or ammonia! A hope is also to have a depression..., because prices get then down to their rock-bottom levels!

The next big item after capital is the crew cost for 26 persons in this case-study. The size of the crew is determined by ship's flag, and by how much the ship is automated. The payable wages are determined by flag, and there is a minimum specified by ILO (international labor Office) or ITF (international transport workers association). Certain states determine the number of crew and the rank as well nationality and they also have to be paid accordingly to a wage agreement valid in their country.

It is strange, but we will insist to argue that a good luck of shipping industry comes from... depressions. The 1981-1987 dry cargo depression allowed the emergence of the "dual registries" in EU; the opening-up of the Eastern Europe $^{22}$, which provided abundant well-educated seamen (Ukraine; Rumania; Poland; Bulgaria etc.). The Indian Sub-Continent as well Philippines was and still are for years the main supply centers of sea labor. The knowledge of English by certain nations like India, Philippines, Nigeria etc., but China, provides a passport to be on board plus the required education.

As a result of the above discussion, the shipowner has to select a flag for the ship that provides him certain competitive advantages like lower crew wages, paying or not national insurance contributions, selecting freely crew nationality and its rank, etc.

Certain shipowners and Onassis as well Niarchos have chosen flags in the

${ }^{22}$ Table 3. 
so-called area of "flags of convenience" for the freedom they provided in business decision-making! In fact, a flag provides a number of monetary benefits as well a number of disadvantages. The main motive is how much tax one pays under each register. As taxation is a considerable cost on net income, this item is a strong motive to choose a flag.

Important is how tax is calculated. Greeks have asked, and EU accepted it, to calculate tax for a ship-owning company as $\$$ on the tonnage of the ship and her size as well age (known as "tonnage tax"). This was so as all efforts to estimate ship's net profit have failed. As a result, crew wages, the number of crew/and its nationality and ship taxation are three strong factors in order to choose a flag. However, flag choice needs a still deeper study.

Table 4 below gives an idea for 1979-1982 for the net basic wage in $\$$ of an able seaman among 6 top shipping nations (free of overtime and extras).

As shown, USA is the most expensive flag, i.e., 3.4 times more expensive than Greece $(1979=100)$. Greeks as shown adopted small increases in sea labor cost. The 1981-1984 depression influenced crew wages. The crew cost situation in 1980 is shown in Figure 9. The Indian crew is 3 times less expensive than Germany.

As shown in Figure 10, the USA flag was more than 5 times more expensive than Singapore. Worth noting is that USA employed 25 persons against 30 of Singapore and the crew cost covered $57 \%$ of the shipping $\operatorname{cost}^{23}$ (USA). Singapore had 39\% crew cost in total shipping cost. The competitive advantage is substantial between Singapore and USA and equal to $\$ 1.7 \mathrm{~m}$ p.a.

A re-emerging problem in international shipping is the availability of officers given that ratings are rather in oversupply. This issue is followed by frequent studies carried-out by ICS (international chamber of shipping) and BIMCO, titled "new seafarer work-force report". Thus, 89,510 officers will be required in

Table 4. Basic wage of an able seaman, US\$ per month of 6 main shipping nations, $1977-1984$

\begin{tabular}{cccccccc}
\hline Year & Greece & Japan & Liberia 1 & Liberia 2 & Norway & UK & USA \\
\hline 1977 & $\$ 292=100$ & $528=181$ & $531=182$ & - & $802=275$ & $295=101$ & $804=275$ \\
1978 & $381=130$ & $534=183$ & $579=198$ & - & $829=284$ & $360=123$ & $865=296$ \\
1979 & $\$ 425=100$ & $590=139$ & $621=146$ & $440=103$ & $900=212$ & $400=94$ & $1022=240$ \\
1980 & $436=103$ & $693=163$ & $674=159$ & $478=112$ & $947=223$ & $567=133$ & $1060=249$ \\
1981 & $428=101$ & $758=178$ & $684=161$ & $499=117$ & $869=204$ & $545=128$ & $1081=254$ \\
1982 & $455=107$ & $752=177$ & $780=183$ & $554=130$ & $877=206$ & $559=131$ & $1294=304$ \\
1983 & $445=105$ & $784=184$ & $821=193$ & - & $888=209$ & $516=121$ & $1323=311$ \\
1984 & $396=93$ & $777=183$ & $821=193$ & - & $764=180$ & $449=106$ & $1448=341$ \\
\hline
\end{tabular}

Source: Lloyd's Shipping Economist, 1982 August. Transformed into US\$. Liberia 1 = ITF global wages; Liberia 2 = wages Far East.

${ }^{23}$ Shipping costs cover crew, maintenance \& repairs, stores, lubricants, general expenses. 


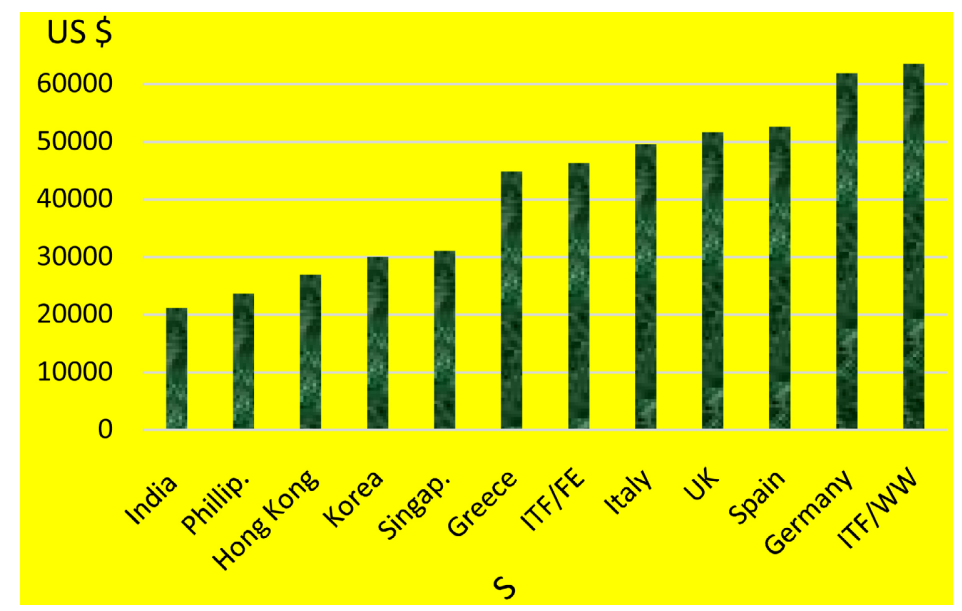

Figure 9. Analysis of monthly total crew costs for vessels of $6000-15,000$ dwt, 1980. Source: "Fairplay" Int. shipping weekly, 04/12/1980. Data includes: basic salary, overtime, leave, bonus and overlap.

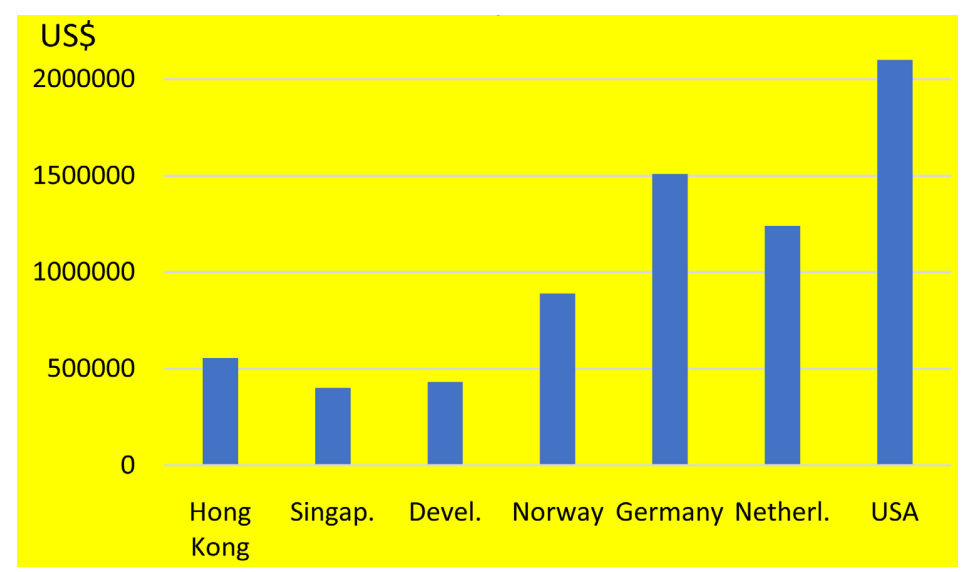

Figure 10. Annual crew cost for a 25,000 dwt bulk Carrier, 1980. Source: author; data from Sturmey, St., unknown date, p. 34. Devel. means a developing country.

next 5 years, as estimated. In 2021 an almost 11\% increase in the supply of officers, since 2015 has occurred. Anyway, shipping contributes to worldwide employment by employing $1.89 \mathrm{~m}$ seafarers on board 74,000 ships ( 25 persons per ship on average). Given that demand for sea labor is greater than supply, the sea wages in officers, we believe, will be increased. Moreover, the expansion of containerships will intensify demand for sea officers.

\subsection{Fuel Cost $\sim 20 \%$}

The fuel cost depends mainly on distance to be covered, on ship's speed, and on the fuel consumption of the main engine. The oil prices are determined exogenously to the shipping company, and since end-1973, the fuel cost is a serious cost item. The shipowner may select the cheaper main engine he prefers, and its speed, then fuel consumption comes automatically in quantity. Captains may economize on fuel when in ballast or in slow steaming by applying a moderate 
speed. There are cases where Captain may intensify the power of the main engine and achieve a maximum speed, but also a maximum fuel consumption.

The type of fuel to be used nowadays is a great question mark and various candidates have appeared like LNG, hydrogen, ammonia, etc., with a view not to discover a cheaper and more powerful sea fuel, but the one most friendly to air environment. This when finalized, will consist the most extraordinary technical progress since 1900 when private cars adopted fuel-oil as fuel for their engines!!

Larger shipping companies have an advantage as they may get volume discounts on fuel to be consumed (Figure 11).

As shown in Figure 11, in 1979, the oil fuel price more than doubled, till 1985, due to "Yom Kippur war", the "Iranian revolution" and the "netback pricing ${ }^{24}$ ". OPEC, a cartel of governments, caused the rises in oil price. Between 1986 and 1999 with the exception of 1990 the oil prices fell near \$20. In 2000, however, an upward trend took place again for the oil price to reach $\$ 111$ by 2011! Pandemic in 2019 led oil price down to about $\$ 40$.

The reasons for seeking for a "better" fuel oil, are not the same each time. Recently everybody realized, we believe, and par excellence EU, as well USA after Trump administration, that environment is vital; and for us is the fourth factor of production, and we have to include it into production function, and pay the cost to preserve it (Goulielmos, 2020).

Climate will revenge the un-clever man, who believed that he is more powerful than mother-Nature! Germany's 150 dead have proved this in July-August 2021 followed by other floods in Belgium, China and fires in USA, Turkey, Greece and Italy.

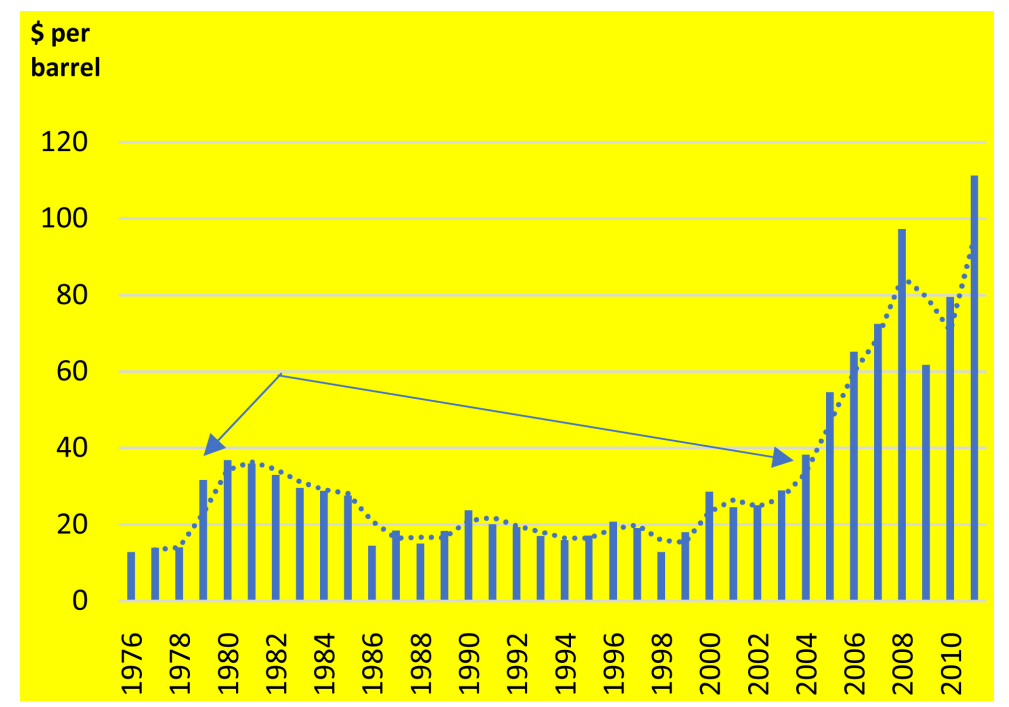

Figure 11. Spot crude oil prices in Brent, 1976-2011. Source: author; data from BP statistical Review, June 2012. $\left(^{*}\right)$ 1976-1983 forties; 1984-2011 Brent dated.

${ }^{24}$ The price of oil after 1973 included all costs from extraction to buyer. 
When the fuel oil is expensive, the substitution law of economics holds, pointing to the use of even coal; and natural gas, methanol, hydrogen, schist, etc. Moreover, the expensive fuel oil triggered the so-called "energy reservation measures" for the first time! Nations embarked in finding their own sources of oil (North Sea; Alaska; Aegean etc.) and other sources more friendly to the environment. But the effort was not uniform and it was in a grave delay.

As shown in Figure 12, to increase the speed of a Panamax from 11 knots to 15 (36.4\%), the consumption of fuel has to increase by $257 \%$, from 14 tons to 36 ! Main sea engines manufacturers did not succeed to construct a ship engine to consume a lower quantity of fuel, despite certain advances that have occurred after end-1973 and mainly after 1979, when fuel cost jumped-up (Goulielmos, 2020).

\subsection{Port Costs 7.2\%}

Port and canal costs are rather excessive and they differ widely from port to port. Ports are rather monopolistic or even monopolies. Shipowners may negotiate port expenses as they do with agency fees. Goulielmos (2021a) showed that $61 \%$ of the revenue of a large tanker is absorbed by the ports! The only economies that shipowners may do are to ask for a few tugs as possible. The captain may minimize the port stay to the absolute necessary. One solution is to have on board more powerful pumps for tankers.

For the dry cargo ships the appropriate gears and the faster hydraulic hatch covers have to be seriously considered. Port time is a delivery of cargo time and it is unproductive. Thus, the port time has to be minimized. Greek shipping used to excel in the past that most repairs, maintenance etc. were done while at sea. Chartering and operations departments may design the entire voyage so that off-hire time to be the minimum possible. This is why that elsewhere we recommended a crew member(s) having a multiple education as well that about engines, maintenance and repairs at sea. The time lost by a ship is also in repairs,

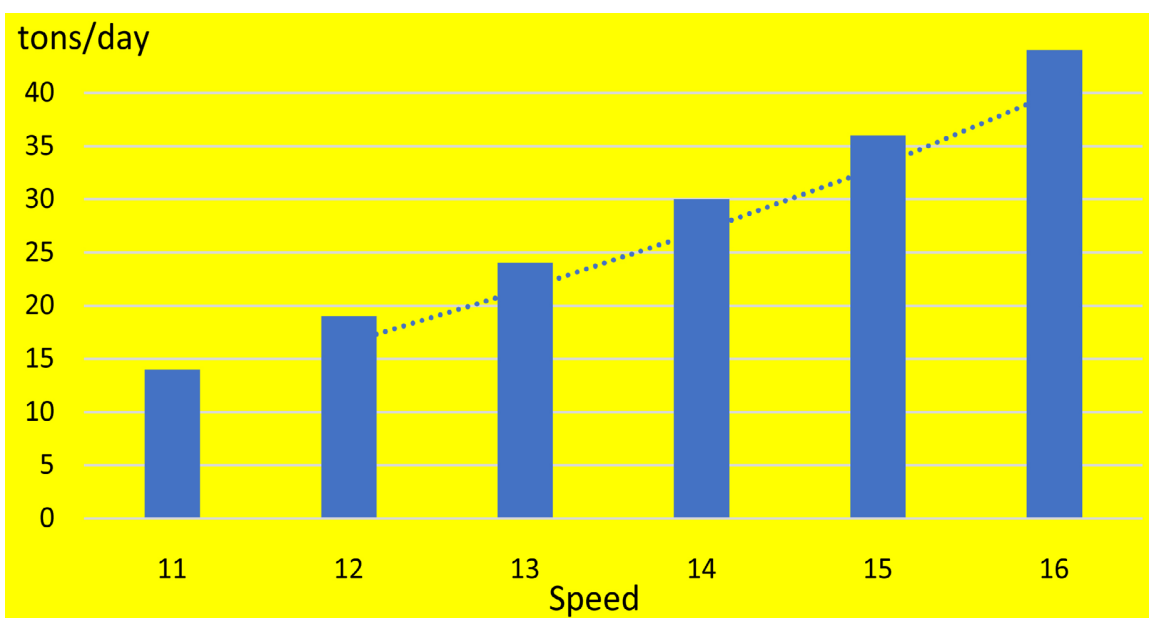

Figure 12. Speed \& fuel consumption of the main engine of a Panamax bulk carrier. Source: data from Stopford (2009), p. 235. 
in dry-dockings, waiting for berth, tugs, launches etc.

\subsection{Insurance Cost $~ 1.93 \%$}

Insurance cost depends on the insured amount, on the age of the vessel, her accident history over last 5 years, flag, and geographical area of her trade. Role plays the so-called deductible amount. The higher the deductible amount, the lower the insurance cost, ceteris paribus. Deductible is the \$ amount that shipowner accepts to have it self-insured, and thus is deducted from any claim. The shipowner may adopt a strategy here so that the amount saved from insurance premiums is greater than the $\$$ amount paid from self-insurance.

Insurance companies make a simple calculation for every ship over a period of say 4 years, and they add all the $\$$ claims they have paid for the vessel and deduct the insurance premiums they have received, excluding big accidents on the valid assumption that these cannot happen every day! If the result is against them, they increase the insurance premium as there are there not to lose money. The basis of any insurance is the risk insured to be random. Risks that are certain, or taking place now, they are not insured.

The probability for a risk to happen must be low and in any way not all insured agents will face it. In fact, the more ships are insured, the better, as a tiny proportion will only be needed to get a compensation. In case, however, that an insurance is seen as a "cow" to provide cash for a claim "manufactured" or "designed", then risk becomes systematic and not at all random (Goulielmos et al., 2002; Goulielmos, 2004).

In the past, shipowners were leaving an insurance company which was asking increases in insurance premiums and in a sense bypassing ship's claim history. Now, history of claims accompanies the ships everywhere. The insurance cost is quite important, and in the past showed a sudden and large rise at times and concentrated on certain flags or ship ages. Various countries tried to create a national insurance market (USA, Italy, Germany, Greece etc.). The most famous and historically $1^{\text {st }}$ insurance market is that of UK Lloyd's starting from a Coffee house. The members of this insurance syndicate guarantee their commitments by their entire personal property!

\section{Research Limitations}

The paper destined to convince readers that managing maritime costs are the $\mathrm{A}$ and $\mathrm{Z}$ of running a shipping company successfully. Also, to show that certain costs, of the greatest importance, appear first, like capital cost. Most costs in the duration of a depression cannot be undone or even reduced. The shipowner is trapped by his/her previous uncareful decisions.

So, the message here is that if you want to excel in shipping learn well that shipping costs have their own ... timing. Given that market determines the price of the shipping services, in dry and liquid cargoes, there is no shipowner, sooner or later, who will not to come in face with a shipping depression. 
This paper is an aide de memoir for one to be well prepared. Onassis by dying in 1975 experienced the oil depression in end 1973 for only 1 - 2 years, unlike Niarchos who spent 9 years with it. As mentioned by Stopford (p. 106) every 8 years, a shipping crisis will emerge... Ship-owning in Homer's Odyssey means apropos "to be prepared".

Some may say that the emphasis paid on certain cost elements had to be more intense, like e.g., on taxation, or the cost from the choice of a particular flag. In fact, we had to make selections and deliver our empirical and theoretical experience.

Greeks in a depression concentrated to cut-down by $20 \%$ crew cost! They could reduce capital cost, the Goliath in costs, covering $50 \%$ of all costs, if they had applied perfect timing in all ship-purchases and new-buildings, provided they were able to reverse time! But who is? This paper indicated where decisions can be wrong and when, and with no regrets. Perfect timing requires patience! You buy either cheap or not at all...

\section{Conclusion}

We showed that there are 7 basic issues that a shipowner has to decide about at the outset. Even management services are available from $3^{\text {rd }}$ parties. The great competitive advantage, however, is derived from Capital cost and this can be determined at the time of purchasing or building moment. This is the first strategy a shipowner should apply in a perfect timing process. Moreover, the insured value of a vessel should be always in line with ship's market value.

We advanced the theory that a prospective shipowner should start from the $2^{\text {nd }}$ hand market, and he can build statistical models between price and age for the shipping sizes and types he/she is interested in. We showed diagrammatically that one and the same vessel had a top price \$38 $\mathrm{m}$ in 1991 as new and $\$ 4 \mathrm{~m}$ in 1985 as used!

Deep knowledge of the shipping market and its mechanics is quite a strong element to retain company's competitive advantage. The shipping manager does not need so much to know about how to achieve the maximum income, but the minimum cost! The freight rate is determined by Supply and Demand exogenously to shipping company... The dry shipping market is depressed since end-2008 (to 2021).

Shipping is perhaps the only industry, (all transportation industries) where demand is determined by the distances involved. Though Suez Canal provides a great saving of steaming of about 11 days, we reckon that its transit +cost is high.

The contribution of this paper, if we wanted to single out one, is the anatomy of maritime costs, where capital cost can arrive at $\$ 5 \mathrm{~m}$ p.a. for a newly-built tanker of small size (30,000 dwt) (51\% of total cost). Our suggestion for the shipowner to be in the $2^{\text {nd }}$ hand market was corrected by the case-study of the 2003-2004, where $2^{\text {nd }}$ hand prices were higher than those of the new-buildings! Unbelievable! 
A rather extensive analysis, a $2^{\text {nd }}$ important contribution, devoted to sea labor cost. Though the number of crew on board was diminished substantially through technical progress, maritime economies failed to create/prepare the proper number of officers and as a result 89,510 officers will be officially missing in near future. Worth noting is that a number of nations, which provide now seamen emerged from former socialist countries in Eastern Europe, but the appearance of "dual registries" opened the door to European fleets to use foreign labor. The hopes, in my personal opinion, rest on the overpopulated nations (China; India) to provide sea officers with proficiency in English.

Last but not least is the future of the marine fuel. To be fair with this issue, we will devote another paper for this important matter.

\section{Conflicts of Interest}

The author declares no conflicts of interest regarding the publication of this paper.

\section{References}

Alderton, P. M. (1980). Sea Transport: Operation and Economics.

Buckley, J. J. (2008). The Business of Shipping (8th ed.). Cornell Maritime Press.

Goulielmos, A. M. (1974). A Vintage Model Approach to Some Problems of Shipping Economics. Doctoral Thesis Awarded by Brunel University, Middlesex.

Goulielmos, A. M. (2004). A Treatise of Randomness Tested Also in Marine Accidents. Disaster Prevention \& Management, 13, 208-217. https://doi.org/10.1108/09653560410541803

Goulielmos, A. M. (2020). Society in Front of 2 Enemies: Covid-19 \& Climate Collapse/Their Impact on Shipping Industry. Modern Economy, 11, 2006-2026. https://doi.org/10.4236/me.2020.1112134

Goulielmos, A. M. (2021a). Scale Economies: An Economic Blessing? Should We Build Still Larger Ships? Modern Economy, 12, 1296-1319. https://doi.org/10.4236/me.2021.128068

Goulielmos, A. M. (2021b). Managing Shipping Companies, the Way Their Pioneers Did: The Case-Studies of Vafias N Family and Aristotelis S. Onassis. Modern Economy.

Goulielmos, A. M. (2021c). Why the Perfect Timing Achieved by the Managers of Shipping Companies Is So Important? Modern Economy, 12, 597-622.

Goulielmos, A. M. (2021d). To Be or Not to Be Listed? A Dilemma of the Greek-Owned Cyclical Shipping Companies, 1993-2018. Modern Economy, 12, 401-428. https://doi.org/10.4236/me.2021.123031

Goulielmos, A. M., Giziakis, C. V., \& Pasarzis, M. (2002). Should Marine Insurance Companies Take Seriously Chaos Theory? Disaster Prevention \& Management, 11, 312-319. https://doi.org/10.1108/09653560210447008

Goulielmos, A. M., Giziakis, V. C., \& Palari, B. (2011). The Advantages and Disadvantages of Managing Own Ships by a Third-Party Ship Management Company: An Empirical Investigation. Shipping \& Transport Logistics, 3, 126-150. https://doi.org/10.1504/IJSTL.2011.039375

Goulielmos, A. M., Lun, V. Y. H., Ng, D. C. T., \& Cheng, E. T. C. (2010). The Business of 
Shipping. Shipping and Transport Logistics Book Series, Volume 2. Inderscience Enterprises Ltd.

Lorange, P. (2009). Shipping Strategy, Innovating for Success. Cambridge University Press.

Spencer, F. A. (1987). A Model for Estimating Cargo Ship Costs. Occasional Paper 83, Federal Bureau of Transport Economics, Australian Government Publishing Service, Canberra with a DISC.

Stopford, M. (2009). Maritime Economics (3rd ed.). Routledge. https://doi.org/10.4324/9780203891742 